\title{
DEFINING DESIGN PARAMETERS FOR HOUSING DEVELOPMENT IN TROPICAL CLIMATES USING THE NEAR ZERO ENERGY HOUSE (nZEH) CONCEPT
}

\author{
Yusuf Latief ${ }^{1 *}$, Mohammed Ali Berawi ${ }^{2}$, Ario Bintang Koesalamwardi ${ }^{3}$, Leni Sagita Riantini ${ }^{4}$, \\ Jade Sjafrecia Petroceany ${ }^{5}$ \\ ${ }^{1}$ Professor, Civil Engineering Department, Faculty of Engineering, University of Indonesia \\ ${ }^{2}$ Associate Professor, Civil Engineering Department, Faculty of Engineering, University of Indonesia \\ ${ }^{3}$ Lecturer, Construction Engineering and Management, Faculty of Engineering, Universitas Agung \\ Podomoro \\ ${ }^{4}$ Lecturer, Civil Engineering Department, Faculty of Engineering, University of Indonesia \\ ${ }^{5}$ Lecturer, Civil Engineering Department, Faculty of Engineering, University of Pancasila
}

(Received: January 2017 / Revised: July 2017 / Accepted: December 2017)

\begin{abstract}
In an effort to support carbon footprint reduction in housing development, one approach is designing energy efficient housing. Issues such as cost efficiency and minimum environmental impact should be thoroughly considered when designing this type of housing. One of concepts found to be cost-effective and to increase the energy performance of a house is the near Zero Energy House (nZEH) concept. This concept enhances the use of natural resources, for example, sunlight exposure, climate conditions, and wind, that can minimize the use of fossil fuel energy. Housing in a tropical climate where sun exposure is year round, such as in Indonesia, can benefit from the nZEH concept. This research aimed to identify design parameters of nZEH and its best practices in tropical climates, including Indonesia. The identified design parameters will be used in the next step of the research, finding a combination of cost optimum design parameters. This study was conducted by consulting recognized experts, which included government, private sector, and academicia, who have expertise in the field of building design and energy. The results showed that the design parameters of nZEH in tropical areas include passive design, fenestration, indoor lighting arrangements, and the use of photovoltaic panels (PV).
\end{abstract}

Keywords: Design parameters; Energy; Near zero energy house; Tropical climates

\section{INTRODUCTION}

A country's economic development is contingent upon its energy sustainability, which includes utilizing renewable energy concepts. In housing development, designing energy efficient housing is one of the approaches for supporting renewable energy concepts. The environmental impact of housing, such as $\mathrm{CO}_{2}$ emissions, depends on the house's overall design, where every aspect affects the house's energy performance. To improve its performance, a concept called near zero energy house (nZEH) is found to be a cost-effective solution. This concept mostly supports the use the natural resources and internal energy from the house/building, which enables the building to generate its own saved energy and minimize energy usage from sources

\footnotetext{
*Corresponding author's email: latief73@eng.ui.ac.id, Tel: +62-21-7270029, Fax: +62-21-7270028 Permalink/DOI: https://doi.org/10.14716/ijtech.v8i6.719
} 
outside the building (Torcellini et al., 2006). Furthermore, Haslam and Farrell (2014) highlighted that nZEH is a building that consumes only slightly more energy than it generates. Tropical climate areas, such as Indonesia, are the best possible locations for utilizing renewable energy technology, that is, solar energy, and applied through the nZEH concept. This is due to its location on the equator and the fact that it is lighted by the sun year round (Zhou et al., 2001; Evola et al., 2014; Koesalamwardi, 2014; Rattanongphisat \& Rordprapat, 2014).

nZEH has been adopted and implemented throughout the world, for example, there are Ecoterra nZEH in Canada, which is equipped by building-integrated photovoltaics (BIPV); the Pearl River Tower in China that uses wind turbines, BIPV, radiant slabs, and natural lighting control system with the building designed by combining site orientation, building shape, natural lighting and automated building control systems; and Canadian Solar and Green City Energy in Haertensdorf, Germany, which uses solar power plants with a capacity of $1 \mathrm{MWp}$ on 16 rooftops with total area of 17,000 $\mathrm{m}^{2}$ (Bucking et al., 2013; Ibanez, 2010).

According to Boeck at al. (2013), there are six main design parameters for nZEH. These parameters were compiled from 65 studies on energy efficiency in housing and nZEH, mainly for sub-tropical climates. The design parameters are as follows:

- Renewable energy technologies, namely the use of photovoltaic (PV) panels (a) the ratio of the panel area-roof area and (b) direction azimuth (orientation) of PV panels

- The shape of the building (a) building orientation and (b) the slope of the roof

- Building envelope that affects insulation

- Fenestration (windows and doors) with the components of the window glazing type, window-to-wall ratio (WWR), window sill type, window direction, internal and external shading

- Heating-ventilating-air conditioning (HVAC) as they are affected by natural ventilation and mechanical cooling/heating

- Lighting

Because the geographical parameter of tropical climates differs from the sub-tropical one, Koesalamwardi (2014), Latief et al. (2016), and Listijono (2014) identified the design parameters for nZEH housing in tropical climates (case study: Indonesia) through the experiment of modeling 400 design scenarios and a case study of Pluit Residential Housing. From the study, the nZEH design parameters that can be used in the tropical climate are: building orientation, PV panels, fenestration, and passive design. Before these can be used to further optimize the design of nZEH, particularly in Indonesia, these parameters need to be validated by relevant experts. This paper discusses the objective of the study, which is to clarify the identified design parameters for nZEH housing in tropical climates.

\section{METHODOLOGY}

A focus group discussion (FGD) of several notable experts was conducted on 18 August 2016 to validate the defined design parameters that were found to be suitable for tropical climates such as Indonesia. Seven experts participated in the discussion representing the government (one expert from the Ministry of Energy and Mineral Resources of Indonesia), academics (one professor and two associate professors from Civil Engineering and Architecture, focusing on building science), and green building consultants (three experts). These experts have more than 10 years' experience in their respective affiliations. In addition, eight researchers who focus on green building and building science also participated in the event.

The discussion identified the design parameters of nZEH for tropical climates from literature reviews (Latief et al., 2016; Boeck et al., 2013), which were first explained by the research 
team. Following that, a comprehensive discussion was conducted. The key questions of topics discussed were as follows:

1) Construction specifications: What types of construction components are relevant regarding energy usage?

2) PV panels: What factors need to be considered when using photovoltaic (PV) panels as the chosen renewable energy technology for a house?

3) Passive design and building orientation: What types of features/specifications of the passive design should be considered for the nZEH concept?

4) Fenestration: What types of fenestration features/specifications should be considered for the nZEH concept?

5) Lighting: What types of lighting features/specifications should be considered for the nZEH concept?

6) Other housing features: What other factors/features should be included in the nZEH concept?

All of the key questions were discussed in the context of usage in tropical climates, particularly in Indonesia. The experts shared their opinions based on their respective experiences and studies on energy efficiency for housing, green building, building science, and related topics. The identified design parameters then will be used in the next step of the research, finding the best combination of cost optimum design parameters.

\section{RESULTS AND DISCUSSION}

The answers and recommendations from the experts summarized from the FGD are described in the following section. A summary of the discussion is shown in Table 1, where the subparameters are rated from 1 (highly insignificant) to 5 (very significant).

Table 1 Design parameters findings

\begin{tabular}{cllc}
\hline No. & Design parameters & Sub-parameters & Ratings by Experts \\
\hline 1. & Construction & a. Roof & 1 \\
& specification & b. Attic & 2 \\
& & c. External door & 2 \\
& & d. Window & 4 \\
& & e. External wall & 5 \\
\hline 2. & PV panels & a. PV capacity & 4 \\
& & b. PV azimuth & 4 \\
& & c. PV tilt & 4 \\
\hline 3. & Passive design & a. Building azimuth & 3 \\
\hline 4. & Fenestration & a. External shading & 2 \\
& & b. Glazing & 2 \\
\hline 5. & Lighting & a. Artificial lighting & 4 \\
\hline 6 & & b. Natural lighting & 4 \\
\hline 6 & Other housing & a. Ease of energy monitoring & 4 \\
& features & b. Ease of operation and maintenance & 3 \\
\hline
\end{tabular}

\subsection{Construction specification}

In the focus group discussion, most of the experts suggested that external wall specification is the most influential housing component with regard to energy usage (5 out of 5 rating), followed by windows and doors ( 4 out of 5 , and 2 out of 5 ratings, respectively). Common 
external wall construction material in tropical countries, for example, hollow bricks with cement finish are a cost optimum selection for saving initial construction costs while providing energy saving insulation. Wooden doors and clear windows are sufficient with regard to cost and energy savings (Latief et al., 2017). Other construction components that have lesser impact on energy usage in a house are insulation, roof design, and ceiling. The application for insulation should be more emphasized on wall structure, with additional considerations, for example, U-value, radiant cooling application, conductivity, and insulation quality for inner and outer walls.

Moreover, the experts from the government and the green building consultant recommended that the HVAC system of a house also be considered and found to be relevant to energy usage. Tropical climate housing needs a compatible air conditioning specification towards its climate. Currently, air conditioning systems that are marketed in tropical countries (e.g., Indonesia) are mostly designed for building/housing in a four-season geographical location. Hence, the energy efficiency of this type of air conditioning system would not fully perform in tropical areas.

Design parameters that could minimize the use of air conditioning are utilizing the window component through window-to-wall area ratio (WWR). For tropical areas such as Indonesia, WWR that ranged from 15-40\% was considered to be optimum for natural lighting during the day without letting an excessive intrusion of heat energy from solar radiation enter the house. Besides WWR, the choice of glazing may affect the amount of heat intensity of solar radiation (Latief et al., 2016). Besides glazing, other cheaper alternatives include using eaves and overhangs (Latief et al., 2017).

\subsection{PV Panel}

The most common renewable energy technology used in nZEH is PV panels. According to experts, there are some significant factors that need to be considered for implementing PV panel in nZEH. The most significant factor is the selection of PV materials (rated 4 out of 5) and technology, for example, mono-crystalline, silicon wafer, etc; each selection has a different capacity and efficiency. Other factors that need to be considered are PB-roof area ratio, installation method, PV azimuth orientation, etc. A previous study by Latief et al. (2016) found that for optimum nZEH design costs, a combination of azimuth is known to maximize the generation of electricity from the PV panel. Azimuth to intensify generation of electricity from the PV panel ranging from -10 to 10 azimuth from the north face orientation was found to be optimum. Latief et al. (2017) found that the optimum tilt for PV panels is $30^{\circ}$. The experts viewed this result as suitable for housing design in tropical climates.

In addition, to reduce initial construction cost, eliminating battery usage by directly connecting the PV installation to the electricity grid can also be considered. This approach should be coordinated with the housing electricity supplier, in this case the government, or the electricity company. Also, the safety of $\mathrm{PV}$ is essential, particularly during its installation and maintenance.

\subsection{Passive Design and Building Orientation}

Our experts also suggested that there are two main considerations when implementing the nZEH concept through passive design, building orientation (3 out of 5) and building materials. Other considerations regarding passive design are initial architect design, building envelope, and roof area. These suggestions are in line with the findings from the literature reviews (Boeck et al., 2013). Placing the building orientation not directly facing the sun (to the west or east) can also reduce direct solar heat radiation, thus minimizing air cooler usage. The optimum building orientation will be facing north and south-south-east (Latief et al., 2017). 


\subsection{Fenestration}

According to the experts, the main factor to be considered in the fenestration design is the window orientation. Following that, a sky lighting vent system could also be considered, where it could be utilized for creating a varied room temperature that could lead to air cooling in the room. This system can also function as natural day lighting. Clear windows can provide adequate natural lighting while reducing initial construction cost by diminishing expensive glazing. However, to reduce heat form solar radiation, applying $60 \mathrm{~cm}$ eaves and overhangs on all windows can help cool indoor room temperature in tropical houses (Lateif et al., 2017).

\subsection{Lighting}

For lighting in the nZEH concept for tropical climates, all experts agreed that the use of natural lighting is essential. As for artificial lighting, some experts suggested that using LED lamps, low E, and energy star lighting systems for night time usage are adequate. Latief et al. (2017) found hardwired CFL lighting, instead expensive LED lighting, is adequate for optimum luminance, while saving material cost and energy.

\subsection{Other Housing Features}

In determining other supporting features for an nZEH design concept, it was the opinion of the experts that the ease of daily energy monitoring should be the main factor to be reviewed. Second, the ease/simplicity of the operation and maintenance of the renewable energy technology and other supporting systems should be considered. This is in line with the Green Building Council in Indonesia; this council developed environmentally friendly housing designs that the public can utilize with ease. Last but not least, the economic factors of using the nZEH design parameters are important. The choice of design and technology for the nZEH concept should also consider their economic costs. For this last factor, a study to optimize the use of the defined nZEH design parameters for economic value is essential.

The summary of the design and material specifications for optimum nZEH design is shown in Table 2.

Table 2 Design parameters specifications (Latief et al., 2017)

\begin{tabular}{|c|c|c|c|}
\hline No. & Design parameters & Sub-parameters & Specifications \\
\hline 1. & $\begin{array}{l}\text { Construction } \\
\text { specification }\end{array}$ & $\begin{array}{l}\text { a. Roof } \\
\text { b. Attic } \\
\text { c. External door } \\
\text { d. Window } \\
\text { e. External wall }\end{array}$ & $\begin{array}{l}\text { a. Terracotta tile } \\
\text { b. R-30 cellulose } \\
\text { c. Wood } \\
\text { d. Clear, double pane } \\
\text { e. } 6 \text { inch hollow block, } \\
\text { medium/dark cement finish }\end{array}$ \\
\hline 2. & PV panels & $\begin{array}{l}\text { a. PV Capacity } \\
\text { b. PV azimuth } \\
\text { c. PV tilt }\end{array}$ & $\begin{array}{l}\text { a. } 4.0 \mathrm{~kW}-5.5 . \mathrm{kW} \\
\text { b. East to north } \\
\text { c. Roof tilt or } 30^{\circ}\end{array}$ \\
\hline 3. & Passive design & a. Building azimuth & a. South-south east or north \\
\hline 4. & Fenestration & $\begin{array}{l}\text { a. External shading } \\
\text { b. Glazing }\end{array}$ & $\begin{array}{l}\text { a. } 60 \mathrm{~cm} \text { eaves and overhangs on } \\
\text { all windows. } \\
\text { b. Clear }\end{array}$ \\
\hline 5. & Lighting & $\begin{array}{l}\text { a. Artificial lighting } \\
\text { b. Natural lighting }\end{array}$ & $\begin{array}{l}\text { a. CFL hardwired } \\
\text { b. } 15 \%-40 \% \text { WWR }\end{array}$ \\
\hline
\end{tabular}




\section{CONCLUSION}

To conclude, the focus group discussion produced further understanding in defining the design parameters for housing development using the nZEH concept, particularly in tropical climates. The main components of a house that would support the nZEH concept are external wall, WWR, glazing, and efficient HVAC system. The use of PV panel should consider the azimuth orientation and choose the most efficient PV specification. Furthermore, the use of passive design is optimized by choosing the most efficient building materials, roof area, and building orientation. Also, in order to provide an alternative HVAC system, the window orientation, the use of a sky lighting vent system, and natural lighting are the main considerations. The nZEH concept for tropical climates cannot be fully in line with the nZEH concept in other geographical areas (e.g., sub-tropical climate). Tropical areas that receive the most solar energy surplus throughout the year, could utilize this advantage by using the most efficient PV panel and supporting fenestration and passive designs.

\section{ACKNOWLEDGEMENT}

The authors would like to acknowledge a research grant from Ministry of Research, Technology and Higher Education Republic of Indonesia (Kemenristekdikti) for the funding support of the research project (Hibah Penelitian Unggulan Perguruan Tinggi 2016 Nomor:1181/UN2.R12/HKP.05.00/2016).

\section{REFERENCES}

Boeck, L.D., Audenaert, A., Mesmaeker, L.D., 2013. Improving the Energy Performance of Residential Buildings: A Literature Review. Hubrussel Research Paper. pp. 1-34

Bucking, S., 2013. Design Optimization Methodology for a Near Net Zero Energy Demonstration Home, s.n., Quebec, Canada

Evola, G., Margani, G., Marletta, L. 2014. Cost-effective Design Solutions for Low-rise Residential Net ZEBs in Mediterranean Climate. Energy and Buildings, Volume 68(Part A), pp. 7-18

Haslam, M.P.G., Farrell, A., 2014. Natural Ventilation Strategies in Near Zero-energy Building: A Design Primer for Students and Professionals. Across: Architectural Research through to Practice, 48 International Conference of the Architectural Science Association, pp. 619630

Ibanez, N., 2010. Digital Construction. Available online at: http://www.constructiondigital.com/sectors/other-construction/german-solar-systeminstalled-ahead-schedule. Accessed on 20 November 2013

Koesalamwardi, A.B., 2014. Cost Optimum Design of Near Zero Energy House using Genetic Algorithm. Master Thesis, Universitas Indonesia

Latief, Y., Berawi, M.A., Supriadi, L., Herzanita, A., Koesalamwardi, A.B., 2017. Near Zero Energy House (nZEH) Cost Optimum Design Development to Improve Economical Value. Ministry of Research, Technology and Higher Education Republic of Indonesia, Hibah Penelitian Unggulan Perguruan Tinggi 2017 - Final Report.

Latief, Y., Berawi, M.A., Supriadi, L., Petroceany, J., Herzanita, A., Koesalamwardi, A.B., 2016. Near Zero Energy House (nZEH) Design Parameters for Housing Development in Indonesia. In: Proceedings of the Third Australasia and South-East Asia Structural Engineering and Construction Conference (ASEA-SEC 3) 2016, Kuching, Malaysia, Oct 31-Nov 4

Listijono, J.B.H., 2014. Pluit Residential House, ASEAN Energy Efficiency and Conservation $(E E \& C)$ Best Practice Competition in Buildings. ASEAN Energy Awards, Vientiane, Laos 
Rattanongphisat, W., Rordprapat, W., 2014. Strategy for Energy Efficient Buildings in Tropical Climate. Energy Procedia, Volume 52, pp.10-17

Torcellini, P., Pless, S. Deru, M. 2006. Zero Energy Buildings: A Critical Look at the Definition. National Renewable Energy Laboratory, Pacific Grove, California, USA

Zhou, A., Alleng, G., Byrne, J. 2001. Using Economic Incentives to Accelerate Development of Green Technologies. Green Building Workshop, Sponsored by the Pacific Energy Center (China) and Environmental Market Solutions, Inc. (U.S.), Shanghai, China, July 9-10 